\title{
ANALISIS VARIASI REKONSTRUKSI INCREMENT OVERLAPPING TERHADAP INFORMASI CITRA ANATOMI PADA PEMERIKSAAN MSCT NASOFARING DENGAN KLINIS KARSINOMA
}

\section{ANALYSIS INCREMENT OVERLAPPING RECONSTRUCTION VARIATION TO ANATOMICAL IMAGE INFORMATION ON NASOPHARYNGEAL MSCT EXAMINATION WITH CARSINOMA CLINICAL}

\author{
Jeffri Ardiyanto ${ }^{1)}$, Darmini ${ }^{2)}$, Widiya Purnama Sari ${ }^{3)}$ \\ ${ }^{1,2,3)}$ Health Polytechnics of Semarang-Indonesia \\ e-mail: jeffri_ardiyanto@hotmail.com
}

\begin{abstract}
Background: In Nasopharyngeal MSCT examination, the radiologist wants optimal image in order to evaluate the characteristics of the tumor, bone destruction due to a tumor, the extent of tumor invasion and the detection of regional metastases that serve as guidelines in determining the clinical stage in patients with nasopharyngeal carcinoma. So setting the scan parameters rekostruksi increments during the process multiplanar reconstruction (MPR) image on Nasopharyngeal MSC T will produce optimal images for diagnosis enforcement. Overlapping reconstruction increment is the distance between the image that has been reconstructed on the data volume that is made smaller than the size of the slice thickness is used. Selection of the reconstruction value increment overlapping usage right has an advantage in generating image anatomical information better for image noise becomes lower and accurate for diagnosing small structures, especially of hidden nasopharynx anatomy and difficult to detect. The purpose of this study was to determine the influence variation reconstruction increment overlapping to the anatomical information image on nasopharyngea MSCT 1 examination with the carcinoma clinical and determine the best value reconstruction increment overlapping that can provide optimal anatomical information image on nasopharyngeal MSCT examination with the clinical of carcinoma.

Methods: This research was quantitative research with pre-experimental approach with one shoot case study method. This research was carried out by means of SIEMENS "SOMATOM EMOTION" - 16 slice in Installing Radiodiagnostic Hospital Dr. Soetomo Surabaya . The data in the form of a data volume of 10 patients in the sample with setting $3 \mathrm{~mm}$ slice thickness and reconstruction increment given the variation of the overlapping $30 \%$ of slice thickness $(0.9 \mathrm{~mm}), 40 \%$ of the slice thickness $(1.2 \mathrm{~mm})$ and $50 \%$ of the slice thickness $(1.5 \mathrm{~mm})$ on MSCT nasopharyngeal examination with the clinical of carcinoma. Assessment anatomical information performed by the two respondents or reviewer. The data analysis was testing the influence with the simple linear regression tets and to determine the value of reconstruction increment overlapping optimal use friedman mean rank test.

Result: The results showed a influence of variation reconstruction increment overlapping to the anatomical information image on nasopharyngeal MSCT examination with the clinical of carcinoma with a significance level of $p=0,000(p<0.05)$. The best value reconstruction increment overlapping that can provide optimal anatomical information image on MSCT nasopharyngeal examination with the clinical of carcinoma is a reconstruction increment overlapping $50 \%$ of the slice thickness $3 \mathrm{~mm}(1.5 \mathrm{~mm})$ with a mean rank in the axial slice and coronal slice image of 2.61 .

Conclution: There are influence of variation reconstruction increment overlapping to the anatomical information image on MSCT nasopharyngeal examination with the clinical of carcinoma with a significance level of $\mathrm{p}=0,000(\mathrm{p}<0.05)$. Reconstruction increment overlapping $50 \%$ of the slice thickness $3 \mathrm{~mm}(1.5 \mathrm{~mm})$ is a best value that can provide optimal anatomical information image on nasopharyngeal MSCT examination with the clinical of carcinoma.
\end{abstract}

Keywords: reconstruction increment overlapping, anatomical information image, MSCT Nasopharyngeal

\section{PENDAHULUAN}

Karsinoma nasofaring merupakan tumor ganas daerah kepala dan leher yang terbanyak ditemukan di Indonesia. Hampir $60 \%$ tumor ganas kepala dan leher merupakan karsinoma nasofaring, kemudian diikuti tumor ganas hidung dan sinus paranasal $18 \%$, laring $16 \%$, dan tumor ganas rongga mulut, tonsil, hipofaring dalam presentasi rendah. Berdasarkan data Laboratorium Patologi Anatomi tumor ganas nasofaring sendiri selalu berada dalam kedudukan lima besar dari tumor ganas tubuh manusia bersama tumor ganas serviks uteri, tumor payudara, tumor getah bening dan tumor kulit (Soepardi dan Iskandar, 2007).

Karsinoma nasofaring adalah tumor ganas yang berasal dari lapisan squamosa atau lapisan epitel respiratorius pada permukaan nasofaring. Nasofaring merupakan ruang atau rongga berdinding kaku yang terletak di belakang rongga hidung atau koana, tepat dibawah dasar tengkorak dan di atas palatum mole serta berhubungan dengan banyak daerah penting di dalam tengkorak dan ke lateral maupun ke posterior leher. Tumor ini bermula dari dinding lateral nasofaring, yang ada fossa Rossenmulleri merupakan lokasi tersering karsinoma nasofaring. Kemudian gejala-gejala akan muncul sesuai arah penyebarannya (Ballenger, 2001).

Letak nasofaring yang tersembunyi dan yang tidak mudah diperiksa akan sulit untuk mendiagnosa penderita secara dini. Seringkali tumor ditemukan terlambat dan 
menyebabkan metastasis ke leher sehingga lebih sering ditemukan sebagai gejala awal (Soepardi dan Iskandar, 2007).

Salah satu modalitas diagnostik yang mampu memperlihatkan karsinoma nasofaring adalah Multi Slice Computed Tomography (MSCT). MSCT merupakan teknik pencitraan sinar- $\mathrm{x}$ canggih, dimana tabung sinar- $\mathrm{x}$ dan beberapa detektor berlapis memutar disekitar pasien, serta dapat mengambil potongan irisan tubuh dalam hitungan detik. Prinsip MSCT adalah pergerakan tabung sinar-x yang berputar secara stasioner dan memancarkan sinar-x secara kontinyu, dengan diiringi pergerakan pasien melewati bidang penyinaran sehingga akan dihasilkan banyak potongan (multislice) dalam satu kali pergerakan (Seeram, 2001).

Massa soft tissue di nasofaring dapat dinilai dengan irisan tipis $(3 \mathrm{~mm}$ ) dan penggunaan dosis tinggi media kontras sangat membantu untuk menilai lesi soft tissue di leher karena media kontras mengikuti perbedaan penampakan pembuluh darah (arteri dan vena), kelenjar getah bening dan tumor (Seeram, 2001). Perluasan karsinoma nasofaring ke dalam rongga hidung, fossa infratemporal, orbita dan rongga kranial sangat baik diperlihatkkan oleh pemeriksaan CT dengan penyangatan kontras (Ballenger, 2003). Kontras enhancement yang dihasilkan oleh media kontras setelah masuk pembuluh darah dibutuhkan untuk mengetahui jika terjadi invasi pada basis cranii, membedakan kontras gambar antara jaringan normal dan abnormal serta untuk mengetahui karakteristik beberapa lesi (Seeram, 2001).

Indikasi pemeriksaan MSCT nasofaring adalah penentuan stadium, mengevaluasi keterlibatan tulang dan desruksi akibat tumor, melihat luasnya invasi tumor, menentukan besarnya tumor, mendeteksi adanya metastasis regional, serta memantau respon tumor terhadap terapi radiasi dan kemoterapi (Hartanto et al. 2011)

Pemeriksaan MSCT Nasofaring menggambarkan ruang nasofaring yang berisi udara, permukaan mukosa, dan bagianbagian fasia dalam nasofaring terlihat baik pada penampang CT axial (horizontal) dan coronal (frontal) (Ballenger, 2003).

Nasofaring normal pada potongan axial melalui bagian tengah nasofaring memperlihatkan septum nasi, konka inferior, torus tubarius, tuba Eustachius dan fossa Rosenmuller, musculus meseter, tensor palatina struktur vaskuler retrosteloid, bagian atas kelenjar parotis serta perhatikan daerah lusen pada ruang parafaring di antara otototot pterigoid dan otot-otot faring. Sedangkan pada penampang semikoronal nasofaring memperlihatkan klivus, muara tuba Eustachius, fosa Rosenmuller, musculus kapitis longus, torus tubarius, musculus pterigoid lateral dan medial, palatum mole, mandibula, musculus maseter dan kelenjar parotis (Ballenger, 2003).

Menurut Silverman cit Baiq (2002), MSCT di nasofaring dibuat dengan irisan axial dan koronal dengan tujuan untuk melihat kelainan yang ada di daerah nasofaring. Irisan axial dimulai dari atas sella tursika sampai dengan tulang hyoid dan irisan coronal dimulai dari tengah palatum durum atau hard palate sampai dengan batas posterior clivus.

Untuk mendapatkan hasil citra yang tepat diperlukan proses reformat gambar. Reformat gambar adalah suatu metode pengaturan data diperoleh dari objek tiga dimensi dari pasien, di produksi oleh komputer dan ditampilkan dalam layar komputer secara dua dimensi untuk memberikan gambaran secara volume. Manfaat dari reformat gambar adalah meningkatkan hasil tampilan sectional anatomi tanpa melakukan scanning pada pasien kembali untuk mendapatkan irisan koronal dan sagital (Seeram, 2001). Gambar potongan tersebut dapat ditampilkan baik secara Multi Planar Reconstruksi (MPR).

Multiplanar Reconstruction (MPR) adalah metode rekonstruksi dengan menggunakan program komputer yang digunakan untuk membentuk gambaran sagital, koronal dan para axial dari susunan gambar axial yang saling berdekatan (Seeram, 2001). Citra pada MPR akan tetap optimal dalam memberikan informasi diagnostik dengan mengatur nilai rekonstruksi increment. Rekonstruksi increment atau yang disebut sebagai interval rekonstruksi atau spasial rekonstruksi merupakan salah satu parameter yang ada pada spiral/ helical $C T$, Rekonstruksi increment merupakan jarak antara citra yang telah di rekonstruksi pada data volume. Menurut Brink et. al (1994) rekonstruksi increment mempunyai keuntungan dalam menghasilkan kualitas gambar yang lebih baik karena image noise yang lebih rendah serta lebih akurat untuk mendiagnosa struktur yang kecil. Jika nilai rekonstruksi increment semakin rendah, maka kualitas gambar meningkat, tetapi dengan konsekuensi meningkatkan waktu untuk processing gambar serta kebutuhan penyimpanan gambar (Seeram, 2001).

Rekonstruksi increment ada tiga cara yaitu increment overlapping, increment contiguous dan increment gap. Pengaturan increment overlapping dibuat lebih kecil dari ukuran slice thicknessnya. Untuk increment contiguous harus dibuat sama dengan ukuran slice thicknessnya. Sedangkan increment gap dibuat lebih besar dari ukuran slice thicknessnya. Penggunaan increment yang tepat akan bisa membuat gambar overlapping sampai $90 \%$, namun untuk tujuan klinis gambar biasanya diatur untuk mendapatkan overlapping 30-50\% dari slice thickness (Siemens Medical, 2003). Menurut Urban et al (1993) dan Seeram (2001) menemukan bahwa deteksi lesi kecil di hati, $50 \%$ overlapping mengakibatkan visualisasi yang lebih baik dari lesi ini sebesar $10 \%$. Pada teknik gambar overlapping dapat diperoleh secara bebas tanpa meningkatkan dosis radiasi pada pasien (Siemens Medical, 2003).

Tujuan dari penelitian ini adalah untuk mengetahui pengaruh variasi rekonstruksi increment overlapping terhadap informasi citra anatomi pada pemeriksaan MSCT Nasofaring dengan klinis karsinoma dan untuk mengetahui nilai rekonstruksi increment overlapping terbaik yang dapat memberikan informasi citra anatomi optimal pada pemeriksaan MSCT Nasofaring dengan klinis karsinoma.

\section{METODE}

Jenis penelitian yang digunakan pada Tugas Akhir ini adalah jenis penelitian eksperimen dengan rancangan penelitian pre eksperimen dan menggunakan metode one shoot case study. Penelitian ini bertujuan untuk mengetahui 
pengaruh variasi rekonstruksi increment overlapping terhadap informasi citra anatomi pada pemeriksaan MSCT Nasofaring dengan klinis karsinoma.

Sepuluh (10) orang pasien berdasarkan kriteria inklusi yaitu pasien dengan klinis karsinoma nasofaring, laki-laki/ perempuan, usia 30 - 50 tahun, tidak ada tindakan operasi/ kemoterapi/ radioterapi dikerjakan pemeriksaan MSCT Nasofaring sebagai sample penelitian. Populasi penelitian adalah semua pasien dengan pemeriksaan MSCT Nasofaring dengan klinis karsinoma di Instalasi Radiodiagnostik RSUD Dr. Soertomo Surabaya selama bulan Oktober - November 2016. Responden atau Reviewer yang memberikan penilaian terhadap citra variasi rekonstruksi increment overlapping adalah 2 (dua) orang Dokter spesialis Radiologi, berjenis kelamin laki-laki/ perempuan dengan pengalamn kerja di bidang radiologi khususnya CT Scan minimal 4 tahun dan masih aktif di bidangnya.

Persiapan Pasien : Melakukan inform concernt dan berikan penjelasan pada pasien mengenai prosedur pemeriksaan yang akan dilakukan. Apabila pasien non kooperatif gunakan immobilisasi untuk mengurangi pergerakan pasien, sehingga tidak menimbulkan artefak yang akan menggganggu gambaran yang akan dihasilkan. Apabila pemeriksaan MSCT Nasofaring menggunakan media kontras sebaiknya pasien membawa hasil laboratorium untuk fungsi ginjal yaitu nitrogen darah $(B U N)$ dan creatinin. Pasien juga dipuasakan 4-6 jam sebelum dimasukkan media kontras dan tanyakan kepada pasien tentang riwayat alergi obat atau makanan. Pasien diinstruksikan untuk tidak menelan selama proses scanning berlangsung untuk menghindari pergerakan.

Persiapan Alat dan Bahan : Peralatan steril meliputi : spuit 20cc, wing nedlee no 21, kapas alkohol, kontras non ionik $50 \mathrm{ml}(1 \mathrm{ml} / \mathrm{kg} \mathrm{BB})$, obat anti alergi (dexametason) $2 \mathrm{cc}$ dan NaCL $20 \mathrm{ml}$.

Peralatan non-steril meliputi : Pesawat CT Scan, selimut, sabuk fiksasi, tabung oksigen, standart infus, injector, printer dan film.

Posisi Pasien : Posisi pasien supine atau terlentang di atas meja pemeriksaan dengan posisi kepala dekat dengan gantry (head first). Kepala pasien diatur hiperekstensi dengan tujuan agar Orbito Meatal Line (OML) sejajar dengan sumbu vertikal gantry dan diletakkan di head holder. Posisikan kepala sehingga Mid Sagital Plane (MSP) sejajar dengan lampu indikator longitudinal dan Inter Pupillary Line (IPL) sejajar dengan lampu indikator horizontal. Kepala difiksasi untuk mengurangi pergerakan. Lengan pasien diletakkan disamping tubuh. Siapkan injektor berisi kontras media 100 $\mathrm{ml}$ dengan konsentrasi $370 \mathrm{mgl} / \mathrm{ml}$. Atur flow rate $1,5-2$ $\mathrm{ml} / \mathrm{s}$. Sambung injector dengan intravena line pasien menggunakan connecting dan threeway. Gambar pertama yang diambil adalah scanogram kepala lateral. Menggunakan scan range dari batas inferior occipital sampai dengan vertebra thorakal 1. FoV mencakup batas lateral dari leher. Irisan axial diambil paralel terhadap vocal cord yang juga paralel terhadap discus intervertebralis servikal. Gantry di tilting untuk mendapatkan sudut yang tepat.
Scan Parameter MSCT Nasofaring : Faktor eksposi 120 $\mathrm{kVp}, 180 \mathrm{mAs}$, Field of View $20 \mathrm{~cm}$, Gantry tilt $0^{\circ}$, Slice thickness 3 mm, Kernel H20s, Rekonstruksi Matriks 512 x 512, Rekonstruksi Algorithma standart CT Nasofaring, Window Width $80 \mathrm{HU}$, Window Level $40 \mathrm{HU}$.

Hasil scanning pada fase kontras direkonstruksikan dengan variasi nilai rekonstruksi increment overlapping yaitu rekonstruksi increment overlapping 30\% dari slice thickness 3 $\mathrm{mm}(0,9 \mathrm{~mm})$, rekonstruksi increment overlapping $40 \%$ dari slice thickness $3 \mathrm{~mm}(1,2 \mathrm{~mm})$ dan rekonstruksi increment overlapping $50 \%$ dari slice thickness $3 \mathrm{~mm}(1,5 \mathrm{~mm})$.

Citra hasil penelitian tersebut disimpan dalam DVD-R dengan format DICOM tanpa ada keterangan identitas apapun, hanya diberikan kode serial citra.

Kemudian dengan menggunakan software RADIANT gambar bisa dilihat dan di reformat MPR guna melihat citra potongan axial dan coronal untuk dilakukan bacaan serta penilaian pada masing-masing kriteria informasi citra anatomi menggunakan kuisioner oleh dua orang responden dokter Spesialis Radiologi sebagai observer

Dua orang Dokter Spesialis Radiologi yang berpengalaman di MSCT Nasofaring dimohon untuk mencermati citra dari masing - masing informasi citra anatomi pemeriksaan MSCT Nasofaring dengan klinis karsinoma pada citra potongan axial dan coronal. Penilaian kualitatif berupa penilaian citra yaitu pada nasofaring space, resessus pharyngeus lateralis (fossa Rossenmuller), torus tubarius, parapharyngeal space, sinus paranasal, internal carotid artery dan kelenjar getah bening (KGB) leher, serta memilih citra terbaik dari 3 variasi rekonstruksi increment overlapping tersebut.

Penilaian oleh Dokter Spesialis Radiologi dilakukan dengan memberikan skor 1, 2, dan 3 pada kuisioner yang telah disediakan. Pertanyaan tentang kejelasan informasi citra anatomi diberikan menurut tingkat kejelasan dengan kriteria penilaian sebagai berikut : Skor 3 berarti "jelas" diberikan apabila informasi citra anatomi MSCT Nasofaring yang diamati tampak jelas, berbatas tegas dan mudah diidentifikasi pada citra potongan axial dan coronal. Skor 2 berarti "cukup jelas", diberikan apabila informasi citra anatomi MSCT Nasofaring yang diamati cukup jelas tetapi tidak berbatas tegas, seperti informasi citra yang diberi skor 3 pada citra potongan axial dan coronal. Skor 1 berarti "kurang jelas", diberikan apabila informasi citra anatomi MSCT Nasofaring yang diamati kurang jelas serta sulit diidentifikasi pada citra potongan axial dan coronal.

Data dari hasil skor penilaian Reviewer merupakan data ordinal, data ini dikonversi menjadi data rasio menggunakan methode successive interval (MSI) agar bisa dilakukan uji regresi linier sederhana. Kemudian data diolah dan dianalisa secara statistika dengan menggunakan software SPSS 17.0. uji regresi linier sederhana dilakukan bertujuan untuk mengetahui ada atau tidaknya pengaruh, kuat dan besar pengaruh. Untuk menentukan nilai rekonstruksi increment overlapping yang optimal dilakukan uji friedman mean rank. 
HASIL

Penelitian dilakukan terhadap 10 (sepuluh) pasien yang dikerjakan pemeriksaan MSCT Nasofaring dengan klinis karsinoma citra potongan axial dan coronal menggunakan pesawat CT Scan merk Siemens "SOMATOM EMOTION" 16 slice di RSUD Dr. Soetomo Surabaya.

Pemilihan keseluruhan sampel berdasarkan kriteria inklusi yang telah ditetapkan peneliti yaitu sampel dengan klinis karsinoma Nasofaring, berjenis kelamin laki - laki 8 (delapan) orang dan perempuan 2 (dua) orang, rentang usia 30 - 50 tahun dan tidak ada tindakan operasi/ kemoterapi/ radioterapi.

Tabel 1. Deskripsi Data Sampel

\begin{tabular}{ccccc}
\hline $\begin{array}{c}\text { Nama } \\
\text { Sampel }\end{array}$ & $\begin{array}{c}\text { Jenis } \\
\text { Kelamin }\end{array}$ & Usia & Klinis & $\begin{array}{c}\text { Tindakan operasi/ } \\
\text { kemoterapi/ } \\
\text { radioterapi }\end{array}$ \\
\hline A & Laki-laki & 47 th & KNF & Tidak \\
B & Laki-laki & 35 th & KNF & Tidak \\
C & Laki-laki & 50 th & KNF & Tidak \\
D & Laki-laki & 45 th & KNF & Tidak \\
E & Laki-laki & 50 th & KNF & Tidak \\
F & Laki-laki & 41 th & KNF & Tidak \\
G & Laki-laki & 30 th & KNF & Tidak \\
H & Perempuan & 43 th & KNF & Tidak \\
I & Laki-laki & 33 th & KNF & Tidak \\
J & Perempuan & 48 th & KNF & Tidak \\
\hline
\end{tabular}

Pada tiap pasien dilakukan pemeriksaan MSCT Nasofaring dengan protokol CT Nasofaring dan pemilihan parameter scan menggunakan slice thickness $3 \mathrm{~mm}$ dan variasi rekonstruksi increment overlapping $30 \% \quad(0,9 \mathrm{~mm})$, rekonstruksi increment overlapping $40 \% \quad(1,2 \mathrm{~mm})$ dan rekonstruksi increment overlapping $50 \%$ (1,5 mm). Hasil penelitian ini berupa data volume pada pemeriksaan MSCT Nasofaring yang menampakkan bagian informasi citra anatomi yaitu pada nasofaring space, resessus pharyngeus lateralis (fossa Rossenmuller), torus tubarius, parapharyngeal space, sinus paranasal, internal carotid artery dan kelenjar getah bening $(K G B)$ leher.
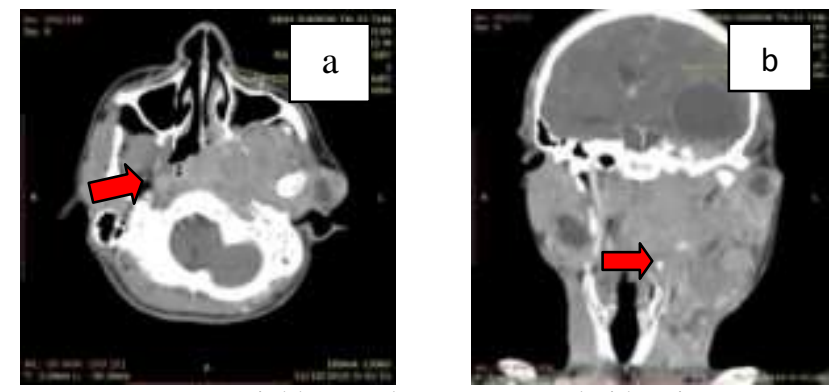

Keterangan : menunjukkan perluasan massa dari karsinoma nasofaring

Gambar 1 Sampel hasil variasi Reconstruksi Increment Overlapping $30 \%$ (0,9 mm) dari slice thickness $3 \mathrm{~mm}$ (a) citra axial (b) citra coronal
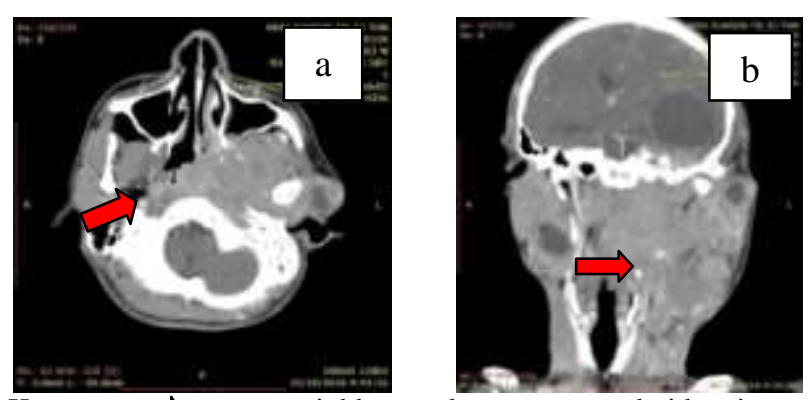

Keterangar $\Rightarrow$ menunjukkan perluasan massa dari karsinoma nasofaring

Gambar 2 Sampel hasil variasi Reconstruksi Increment Overlapping $40 \%$ (1,2 mm) dari slice thickness $3 \mathrm{~mm}$ (a) citra axial (b) citra coronal
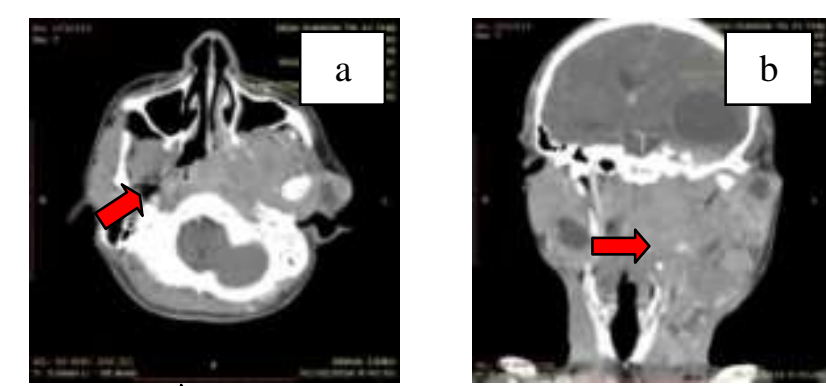

Keterangan $\Rightarrow$ menunjukkan perluasan massa dari karsinoma nasofaring

Gambar 3 Sampel hasil variasi Reconstruksi Increment Overlapping $50 \%$ (1,5 mm) dari slice thickness $3 \mathrm{~mm}$ (a) citra axial (b) citra coronal

Hasil penelitian dari masing-masing sampel pada citra potongan axial dan coronal, terlebih dahulu dilakukan analisa uji statistic Kappa (Realibilty Inter Observer) untuk mengetahui tingkat kesepakatan atau tingkat persamaan persepsi kedua responden atau viewer dalam penilaian kuisioner. Hasil pengujian Kappa terhadap 2 responden adalah sebagai berikut :

Tabel 2. Hasil uji kappa pada kedua respoden

\begin{tabular}{ccccc}
\hline \multirow{2}{*}{$\begin{array}{c}\text { Responden } 1 \text { dan } \\
\text { Responden } 2\end{array}$} & $\begin{array}{c}\text { Citra Axial } \\
\text { Value }\end{array}$ & $\begin{array}{c}\text { Approx } \\
\text { sig. }\end{array}$ & $\begin{array}{c}\text { Kappa } \\
\text { Value }\end{array}$ & $\begin{array}{c}\text { Approx } \\
\text { sig. }\end{array}$ \\
\hline RIO 30\% (0,9 mm) & 0,914 & $<0,000$ & 0,888 & $<0,000$ \\
RIO 40\% $(1,2 \mathrm{~mm})$ & 0,886 & $<0,000$ & 0,858 & $<0,000$ \\
RIO 50\% $(1,5 \mathrm{~mm})$ & 0,870 & $<0,000$ & 0,822 & $<0,000$ \\
\hline
\end{tabular}

Berdasarkan hasil uji kappa pada citra potongan axial dan coronal dapat dilihat value kappa pada keseluruhan variabel independent adalah lebih dari 0,8. Menurut Sopiyudin (2014) kedua observer mempunyai reliabilitas yang baik (minimal Kappa $=0,8)$. Hasil ini menunjukan bahwa ada kesesuaian atau persamaan persepsi antara kedua responden dalam menilai informasi citra anatomi pada pemeriksaan MSCT Nasofaring dengan klinis karsinoma pada keseluruhan variasi rekonstruksi increment overlapping. 
Uji statistik normalitas sebaran data dilakukan pada nilai residual dari data penelitaian untuk menilai baik atau tidaknya model regresi yang akan digunakan. Jika nilai residual data penelitian berdistribusi normal artinya model regresi yang digunakan adalah baik. Metode pengujian yang digunakan adalah Kolmogorov - Smirnov. Data dikatakan berdistribusi normal jika $p$ value $>0,05$.

Tabel 3 Hasil uji normalitas data

\begin{tabular}{lcc}
\hline \multirow{2}{*}{ Informasi Citra Anatomi } & Citra Axial. & Citra Coronal \\
\cline { 2 - 3 } nasofaring space & 0,448 & Asymp.Sig \\
fossa Rossenmuller & 0,498 & 0,498 \\
torus tubarius & 0,211 & 0,211 \\
parapharingeal space & 0,273 & 0,162 \\
sinus paranasal & 0,107 & 0,219 \\
internal carotid arteri & 0,612 & 0,113 \\
kelenjar getah bening leher & 0,067 & 0,058 \\
\hline
\end{tabular}

Berdasarkan tabel tersebut dapat diketahui bahwa data hasil penilaian informasi citra anatomi pada pemeriksaan MSCT Nasofaring dengan klinis karsinoma dari keseluruhan citra anatomi yang dihasilkan berdistribusi normal yaitu $p$ value > 0,05 sehingga dapat dilanjutkan dengan uji regresi linier sederhana.

Selanjutnya untuk uji pengaruh menggunakan uji regresi linier sederhana. Uji regresi dilakukan dua tahap, yang pertama untuk mengetahui pengaruh variasi rekonstruksi increment overlapping terhadap informasi citra anatomi pada pemeriksaan MSCT Nasofaring dengan klinis karsinoma secara keseluruhan dan yang kedua uji regresi dilakukan pada setiap organ penilaian informasi citra anatomi MSCT Nasofaring dengan klinis karsinoma.

Tabel 4. Hasil uji regresi linier sederhana pengaruh variasi rekonstruksi increment overlapping terhadap informasi citra anatomi pemeriksaan MSCT Nasofaring dengan klinis karsinoma secara

\begin{tabular}{lcccc}
\multicolumn{5}{c}{ keseluruhan } \\
\hline Citra Axial & 0,730 & 0,533 & 0,531 & 0,000 \\
Citra Coronal & 0,717 & 0,514 & 0,512 & 0,000 \\
\hline
\end{tabular}

Uji statistik regresi menghasilkan nilai signifikansi $p$ value $<0,05$ yang berarti ada pengaruh signifikan pada pemberian variasi rekonstruksi increment overlapping terhadap informasi citra anatomi pada pemeriksaan MSCT Nasofaring dengan klinis karsinoma. Nilai Adjusted $R$ square pada citra potongan axial bermakna $53 \%$ informasi citra anatomi pada pemeriksaan MSCT Nasofaring dengan klinis karsinoma dipengaruhi oleh rekonstruksi increment overlapping dan sisanya $47 \%$ dipengaruhi oleh faktor lain yaitu slice thickness, faktor eksposi, Field of View (FoV), gantry tilt, rekonstruksi matrix, rekonstruksi algorithma, Window Width (WW) dan Window Level (WL). Sedangkan nilai Adjusted $R$ Square pada citra potongan coronal bermakna $51 \%$ informasi citra anatomi pada pemeriksaan MSCT Nasofaring dengan klinis karsinoma dipengaruhi oleh rekonstruksi increment overlepping dan sisanya $49 \%$ dipengaruhi oleh faktor lain yaitu slice thickness, faktor eksposi, Field of View (FoV), gantry tilt, rekonstruksi matrix, rekonstruksi algorithma, Window Width $(W W)$ dan Window Level (WL). Nilai $R$ menunjukan koefisien korelasi yang sangat kuat antara variasi rekonstruksi increment overlapping terhadap informasi citra anatomi pada pemeriksaan MSCT Nasofaring dengan klinis karsinoma.

Setelah uji regresi linier dilakukan selanjutnya adalah mencari nilai rekonstruksi increment overlapping terbaik yang dapat memberikan informasi citra anatomi optimal pada pemeriksaan MSCT Nasofaring dengan klinis karsinoma. Hal ini dapat diperoleh dengan melakukan uji Friedman Mean Rank. Hasil mean rank tertinggi dari variasi rekonstruksi increment overlapping terhadap informasi citra anatomi menunjukkan nilai rekonstruksi increment overlapping yang terbaik.

Tabel 5. Hasil uji friedman mean rank keseluruhan

\begin{tabular}{ccccc}
\hline \multirow{2}{*}{ Variasi Nilai RIO } & \multicolumn{2}{c}{ Citra Potongan } & \multicolumn{2}{c}{ Citra Potongan } \\
& Mean & Asymp & Mean & Asymp \\
& Rank & Sig. & Rank & Sig. \\
\hline RIO 30\% $(0,9 \mathrm{~mm})$ & 1,09 & 0,000 & 1,12 & 0,000 \\
RIO 40\% $(1,2 \mathrm{~mm})$ & 2,29 & 0,000 & 2,27 & 0,000 \\
RIO 50\% $(1,5 \mathrm{~mm})$ & 2,61 & 0,000 & 2,61 & 0,000 \\
\hline
\end{tabular}

Berdasarkan mean rank yang dihasilkan variasi rekonstruksi increment overlapping $50 \%$ dari slice thickness $3 \mathrm{~mm}(1,5 \mathrm{~mm})$ pada citra potongan axial dan coronal memperoleh nilai tertinggi yaitu 2,61 dibanding dengan yang lainnya, maka dapat dinyatakan variasi rekonstruksi increment overlapping $50 \%$ dari slice thickness $3 \mathrm{~mm}(1,5 \mathrm{~mm})$ adalah variasi terbaik dalam memberikan informasi citra anatomi yang optimal pada pemeriksaan MSCT Nasofaring dengan klinis karsinoma.

Uji regresi linier sederhana setiap organ penilaian dilakukan untuk mengetahui pengaruh setiap kriteria dalam sebuah citra. Hasil uji regresi linier sederhana setiap organ penilaian pada citra potongan axial dapat dilihat pada tabel 6 .

Tabel 6 Hasil uji regresi linier sederhana pada citra potongan axial

\begin{tabular}{lccc}
\hline \multicolumn{1}{c}{$\begin{array}{c}\text { Informasi Citra } \\
\text { Anatomi }\end{array}$} & $R$ & $\begin{array}{c}\text { Adjusted } \\
R \text { square }\end{array}$ & Sig \\
\hline Nasofaring space & 0,779 & 0,593 & 0,000 \\
fossa Rossenmuller & 0,771 & 0,580 & 0,000 \\
torus tubarius & 0,757 & 0,558 & 0,000 \\
Parapharingeal space & 0,721 & 0,502 & 0,000 \\
sinus paranasal & 0,711 & 0,488 & 0,000 \\
Internal carotid arteri & 0,731 & 0,518 & 0,000 \\
KGB leher & 0,675 & 0,437 & 0,000 \\
\hline
\end{tabular}

Terdapat hubungan yang kuat dan signifikan antara variasi rekonstruksi increment overlapping terhadap 
nasofaring space. Ada pengaruh yang signifikan variasi rekonstruksi increment overlapping terhadap nasofaring space dan $59 \%$ nasofaring space dipengaruhi rekonstruksi increment overlapping dan $41 \%$ sisanya dipengaruhi oleh faktor lain yaitu slice thickness, faktor eksposi, Field of View (FoV), gantry tilt, rekonstruksi matrix, rekonstruksi algorithma, Window Width (WW) dan Window Level (WL).

Terdapat hubungan yang kuat dan signifikan antara variasi rekonstruksi increment overlapping terhadap fossa Rossenmuller. Ada pengaruh yang signifikan variasi rekonstruksi increment overlapping terhadap fossa Rossenmuller dan $58 \%$ fossa Rossenmuller dipengaruhi rekonstruksi increment overlapping dan $42 \%$ sisanya dipengaruhi oleh faktor lain yaitu slice thickness, faktor eksposi, Field of View (FoV), gantry tilt, rekonstruksi matrix, rekonstruksi algorithma, Window Width $(W W)$ dan Window Level (WL).

Terdapat hubungan yang kuat dan signifikan antara variasi rekonstruksi increment overlapping terhadap torus tubarius. Ada pengaruh yang signifikan variasi rekonstruksi increment overlapping terhadap torus tubarius dan $55 \%$ torus tubarius dipengaruhi rekonstruksi increment overlapping dan $45 \%$ sisanya dipengaruhi oleh faktor lain yaitu slice thickness, faktor eksposi, Field of View (FoV), gantry tilt, rekonstruksi matrix, rekonstruksi algorithma, Window Width $(W W)$ dan Window Level (WL).

Terdapat hubungan yang kuat dan signifikan antara variasi rekonstruksi increment overlapping terhadap parapharingeal space. Ada pengaruh yang signifikan variasi rekonstruksi increment overlapping terhadap parapharingeal space dan $50 \%$ parapharingeal space dipengaruhi rekonstruksi increment overlapping dan $50 \%$ sisanya dipengaruhi oleh faktor lain yaitu slice thickness, faktor eksposi, Field of View (FoV), gantry tilt, rekonstruksi matrix, rekonstruksi algorithma, Window Width $(W W)$ dan Window Level (WL).

Terdapat hubungan yang kuat dan signifikan antara variasi rekonstruksi increment overlapping terhadap sinus paranasal. Ada pengaruh yang signifikan variasi rekonstruksi increment overlapping terhadap sinus paranasal dan $48 \%$ sinus paranasal dipengaruhi rekonstruksi increment overlapping dan $52 \%$ sisanya dipengaruhi oleh faktor lain yaitu slice thickness, faktor eksposi, Field of View (FoV), gantry tilt, rekonstruksi matrix, rekonstruksi algorithma, Window Width (WW) dan Window Level (WL).

Terdapat hubungan yang kuat dan signifikan antara variasi rekonstruksi increment overlapping terhadap internal carotid artery. Ada pengaruh yang signifikan variasi rekonstruksi increment overlapping terhadap internal carotid artery dan $51 \%$ internal carotid artery dipengaruhi rekonstruksi increment overlapping dan $49 \%$ sisanya dipengaruhi oleh faktor lain yaitu slice thickness, faktor eksposi, Field of View (FoV), gantry tilt, rekonstruksi matrix, rekonstruksi algorithma, Window Width $(W W)$ dan Window Level (WL).

Terdapat hubungan yang kuat dan signifikan antara variasi rekonstruksi increment overlapping terhadap kelenjar getah bening $(K G B)$ leher. Ada pengaruh yang signifikan variasi rekonstruksi increment overlapping terhadap terhadap kelenjar getah bening (KGB) leher dan $43 \%$ terhadap kelenjar getah bening (KGB) leher dipengaruhi rekonstruksi increment overlapping dan $57 \%$ sisanya dipengaruhi oleh faktor lain yaitu slice thickness, faktor eksposi, Field of View (FoV), gantry tilt, rekonstruksi matrix, rekonstruksi algorithma, Window Width (WW) dan Window Level (WL).

Hasil uji regresi linier sederhana setiap organ penilaian pada citra potongan coronal dapat dilihat pada tabel 7.

\begin{tabular}{lccc} 
Tabel 7. Hasil uji regresi linier sederhana pada citra potongan coronal \\
\hline $\begin{array}{c}\text { Informasi Citra } \\
\text { Anatomi }\end{array}$ & $R$ & $\begin{array}{l}\text { Adjusted } \\
R \text { square }\end{array}$ & Sig \\
\hline Nasofaring space & 0,771 & 0,580 & 0,000 \\
fossa Rossenmuller & 0,757 & 0,558 & 0,000 \\
torus tubarius & 0,751 & 0,548 & 0,000 \\
Parapharingeal space & 0,737 & 0,526 & 0,000 \\
sinus paranasal & 0,707 & 0,482 & 0,000 \\
Internal carotid arteri & 0,741 & 0,533 & 0,000 \\
KGB leher & 0,625 & 0,369 & 0,000 \\
\end{tabular}

Terdapat hubungan yang kuat dan signifikan antara variasi rekonstruksi increment overlapping terhadap nasofaring space. Ada pengaruh yang signifikan variasi rekonstruksi increment overlapping terhadap nasofaring space dan $58 \%$ nasofaring space dipengaruhi rekonstruksi increment overlapping dan $42 \%$ sisanya dipengaruhi oleh faktor lain yaitu slice thickness, faktor eksposi, Field of View (FoV), gantry tilt, rekonstruksi matrix, rekonstruksi algorithma, Window Width (WW) dan Window Level (WL).

Terdapat hubungan yang kuat dan signifikan antara variasi rekonstruksi increment overlapping terhadap fossa Rossenmuller. Ada pengaruh yang signifikan variasi rekonstruksi increment overlapping terhadap fossa Rossenmuller dan $55 \%$ fossa Rossenmuller dipengaruhi rekonstruksi increment overlapping dan $45 \%$ sisanya dipengaruhi oleh faktor lain yaitu slice thickness, faktor eksposi, Field of View (FoV), gantry tilt, rekonstruksi matrix, rekonstruksi algorithma, Window Width $(W W)$ dan Window Level (WL).

Terdapat hubungan yang kuat dan signifikan antara variasi rekonstruksi increment overlapping terhadap torus tubarius. Ada pengaruh yang signifikan variasi rekonstruksi increment overlapping terhadap torus tubarius dan $54 \%$ torus tubarius dipengaruhi rekonstruksi increment overlapping dan $46 \%$ sisanya dipengaruhi oleh faktor lain yaitu slice thickness, faktor eksposi, Field of View (FoV), gantry tilt, rekonstruksi matrix, rekonstruksi algorithma, Window Width $(W W)$ dan Window Level (WL).

Terdapat hubungan yang kuat dan signifikan antara variasi rekonstruksi increment overlapping terhadap parapharingeal space. Ada pengaruh yang signifikan variasi rekonstruksi increment overlapping terhadap parapharingeal space dan $52 \%$ parapharingeal space dipengaruhi rekonstruksi increment overlapping dan $48 \%$ sisanya 
dipengaruhi oleh faktor lain yaitu slice thickness, faktor eksposi, Field of View (FoV), gantry tilt, rekonstruksi matrix, rekonstruksi algorithma, Window Width $(W W)$ dan Window Level (WL).

Terdapat hubungan yang kuat dan signifikan antara variasi rekonstruksi increment overlapping terhadap sinus paranasal. Ada pengaruh yang signifikan variasi rekonstruksi increment overlapping terhadap sinus paranasal dan $48 \%$ sinus paranasal dipengaruhi rekonstruksi increment overlapping dan $52 \%$ sisanya dipengaruhi oleh faktor lain yaitu slice thickness, faktor eksposi, Field of View (FoV), gantry tilt, rekonstruksi matrix, rekonstruksi algorithma, Window Width $(W W)$ dan Window Level (WL).

Terdapat hubungan yang kuat dan signifikan antara variasi rekonstruksi increment overlapping terhadap internal carotid artery. Ada pengaruh yang signifikan variasi rekonstruksi increment overlapping terhadap internal carotid artery dan $53 \%$ internal carotid artery dipengaruhi rekonstruksi increment overlapping dan $47 \%$ sisanya dipengaruhi oleh faktor lain yaitu slice thickness, faktor eksposi, Field of View (FoV), gantry tilt, rekonstruksi matrix, rekonstruksi algorithma, Window Width $(W W)$ dan Window Level (WL).

Tabel 8. Hasil uji friedman mean rank test per organ penilaian

\begin{tabular}{|c|c|c|c|c|}
\hline \multirow[t]{2}{*}{$\begin{array}{l}\text { Informasi citra } \\
\text { anatomi }\end{array}$} & \multicolumn{2}{|c|}{$\begin{array}{c}\text { Citra Potongan } \\
\text { Axial }\end{array}$} & \multicolumn{2}{|c|}{$\begin{array}{l}\text { Citra Potongan } \\
\text { Coronal }\end{array}$} \\
\hline & $\begin{array}{l}\text { Mean } \\
\text { Rank }\end{array}$ & $\begin{array}{l}\text { Asymp } \\
\text { Sig. }\end{array}$ & $\begin{array}{l}\text { Mean } \\
\text { Rank }\end{array}$ & $\begin{array}{l}\text { Asymp } \\
\text { Sig. }\end{array}$ \\
\hline \multicolumn{5}{|l|}{ RIO $30 \%(0,9 \mathrm{~mm})$} \\
\hline Nasofaring space & 1.10 & 0,000 & 1,00 & 0,000 \\
\hline fossa Rossenmuller & 1,00 & 0,000 & 1,10 & 0,000 \\
\hline torus tubarius & 1,10 & 0,000 & 1,00 & 0,000 \\
\hline parapharingeal space & 1,05 & 0,000 & 1,20 & 0,001 \\
\hline sinus paranasal & 1,15 & 0,001 & 1,30 & 0,001 \\
\hline internal carotid arteri & 1,00 & 0,000 & 1,05 & 0,000 \\
\hline KGB leher & 1,25 & 0,002 & 1,20 & 0,001 \\
\hline \multicolumn{5}{|l|}{ RIO 40\% (1,2 mm) } \\
\hline Nasofaring space & 2.20 & 0,000 & 2.35 & 0,000 \\
\hline fossa Rossenmuller & 2,35 & 0,000 & 2,30 & 0,000 \\
\hline torus tubarius & 2,30 & 0,000 & 2,45 & 0,000 \\
\hline parapharingeal space & 2,40 & 0,000 & 2,25 & 0,001 \\
\hline sinus paranasal & 2,25 & 0,001 & 2,00 & 0,001 \\
\hline internal carotid arteri & 2,40 & 0,000 & 2,35 & 0,000 \\
\hline KGB leher & 2,15 & 0,002 & 2,20 & 0,001 \\
\hline $\begin{array}{l}\text { RIO } 50 \%(1,5 \mathrm{~mm}) \\
\text { Nasofaring space }\end{array}$ & 2,70 & 0,000 & 2,65 & 0,000 \\
\hline fossa Rossenmuller & 2,65 & 0,000 & 2,60 & 0,000 \\
\hline torus tubarius & 2,60 & 0,000 & 2,55 & 0,000 \\
\hline parapharingeal space & 2,55 & 0,000 & 2,55 & 0,001 \\
\hline sinus paranasal & 2,60 & 0,001 & 2,70 & 0,001 \\
\hline internal carotid arteri & 2,60 & 0,000 & 2,60 & 0,000 \\
\hline KGB leher & 2,60 & 0,002 & 2,60 & 0,001 \\
\hline
\end{tabular}

Terdapat hubungan yang kuat dan signifikan antara variasi rekonstruksi increment overlapping terhadap kelenjar getah bening $(K G B)$ leher. Ada pengaruh yang signifikan variasi rekonstruksi increment overlapping terhadap terhadap kelenjar getah bening (KGB) leher dan $36 \%$ terhadap kelenjar getah bening (KGB) leher dipengaruhi rekonstruksi increment overlapping dan $64 \%$ sisanya dipengaruhi oleh faktor lain yaitu slice thickness, faktor eksposi, Field of View (FoV), gantry tilt, rekonstruksi matrix, rekonstruksi algorithma, Window Width (WW) dan Window Level (WL).

Untuk mengetahui nilai rekonstruksi increment overlapping terbaik yang dapat memberikan informasi citra anatomi optimal pada pemeriksaan MSCT Nasofaring dengan klinis karsinoma setiap organ penilaian menggunakan uji friedman mean rank.

Berdasarkan tabel 7 menunjukkan bahwa hasil uji friedman mean rank diperoleh hasil variasi rekonstruksi increment overlapping $50 \%(1,5 \mathrm{~mm})$ dari slice thickness 3 $\mathrm{mm}$ memperoleh nilai terbesar, maka dapat dinyatakan variasi tersebut adalah variasi terbaik dalam memberikan informasi citra anatomi yang optimal pada pemeriksaan MSCT Nasofaring dengan klinis karsinoma.

\section{DISKUSI}

Salah satu modalitas diagnostik yang mampu memperlihatkan karsinoma nasofaring adalah MSCT Nasofaring. Kemampuannya menampilkan informasi citra anatomi secara tepat dan akurat akan membantu dokter radiolog terutama dalam penentuan stadium karsinoma nasofaring. Rekonstruksi increment sangat menjadi pertimbangan ketika akan melakukan proses rekonstruksi citra Multiplanar (MPR) pada MSCT Nasofaring, agar citra yang dihasilkan menjadi optimal dalam penegakan diagnosa. Hasil uji Regresi pada penelitian ini menunjukkan nilai signifikansi $p$ value $=0,000$ atau $p$ value $<0,05$ sehingga Ho ditolak dan Ha diterima yang berarti ada pengaruh signifikan pada pemberian variasi rekonstruksi increment overlapping terhadap informasi citra anatomi pada pemeriksaan MSCT Nasofaring dengan klinis karsinoma. Interpretasi hasil uji hipotesa secara keseluruhan organ penilaian mendapatkan skor keterpengaruhan yang kuat yaitu untuk citra potongan axial sebesar $53 \%$ dan coronal sebesar $51 \%$.

Rekonstruksi increment yang disebut juga interval rekonstruksi atau spasial rekonstruksi, merupakan salah satu parameter yang ada pada spiral/ helical CT. Rekonstruksi increment merupakan jarak antara citra yang telah direkonstruksi pada data volume. Pemilihan rekonstruksi increment overlapping yang dibuat lebih kecil dari ukuran slice thicknessnya memungkinkan rekonstruksi yang tidak ada celah karena jarak antar image rekonstruksi pada sumbu $\mathrm{z}$ menjadi saling overlap. Setiap kenaikan nilai rekonstruksi increment overlapping maka informasi citra anatomi juga akan meningkat. Oleh karena ketajaman dan detail antar organ menjadi lebih baik. Menurut Siemens Medical (2003) penggunaan increment yang tepat akan bisa membuat gambar overlapping sampai 90\%, namun untuk tujuan klinis gambar 
biasanya diatur untuk mendapatkan overlapping 30-50\% dari slice thickness (Siemens Medical, 2003).

Keuntungan penggunaan teknik rekonstruksi increment overlapping yaitu pada teknik rekonstruksi gambar overlapping ini dapat diperoleh secara bebas tanpa meningkatkan dosis radiasi pada pasien. Sedangkan menurut Brink et al. (1994) pemilihan rekonstruksi increment overlapping yang dibuat lebih kecil dari ukuran slice thicknessnya akan meningkatkan kualitas gambar yang lebih baik karena image noise menjadi rendah dan akurat untuk mendiagnosa struktur organ yang kecil seperti pada anatomi nasofaring yang tidak mudah diperiksa dan letaknya tersembunyi di belakang rongga hidung atau koana, tepat di bawah dasar tengkorak, di atas palatum mole serta berhubungan dengan banyak daerah penting di dalam tengkorak baik ke lateral maupun ke posterior leher. Dimana fossa Rosenmulleri merupakan lokasi tersering munculnya karsinoma atau tumor ganas pada nasofaring. kemudian gejala-gejala akan muncul sesuai arah penyebarannya sehingga seringkali tumor ditemukan terlambat dan menyebabkan metastase ke leher (Ballenger, 2001).

Terlihat jelas pada penelitian ini perbedaan informasi citra anatomi pada pemeriksaan MSCT Nasofaring antara variasi dengan rekonstruksi increment overlapping $30 \%(0,9$ $\mathrm{mm}), 40 \%$ ( $1,2 \mathrm{~mm})$ dan $50 \%(1,5 \mathrm{~mm})$ dari slice thickness 3 $\mathrm{mm}$. Akan lebih jelas batas-batas antar organ dengan rekonstruksi increment overlapping 50\% (1,5 mm) karena akan menghasilkan kontras yang baik antara jaringan normal dan abnormal sehingga dapat membantu dokter radiologi dalam evaluasi karakteristik tumor, evaluasi destruksi tulang akibat tumor, evaluasi luasnya invasi tumor dan deteksi adanya metastase regional sehingga menjadi pedoman dalam penentuan stadium atau staging karsinoma Nasofaring.
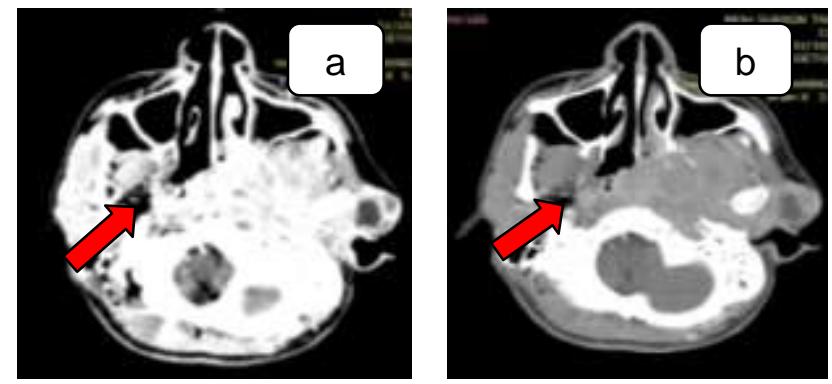

Gambar 4. Sampel hasil MSCT Nasofaring dengan klinis karsinoma pada citra potongan axial (a) dengan pemilihan slice thickness $5 \mathrm{~mm}$ dan variasi rekonstruksi increment overlapping $1 \mathrm{~mm}$ dan (b) dengan pemilihan slice thickness $3 \mathrm{~mm}$ dan variasi reconstruksi increment overlapping $50 \%$ (1,5 mm). Keterangan : tanda panah menunjukkan perluasan massa dari karsinoma nasofaring

Menurut Seeram (2001) massa soft tissue di nasofaring dapat dinilai dengan irisan tipis $(3 \mathrm{~mm})$ dan penggunaan dosis tinggi media kontras sangat membantu untuk menilai lesi soft tissue di leher karena media kontras mengikuti perbedaan penampakan pembuluh darah (arteri dan vena), kelenjar getah bening dan tumor (Seeram, 2001). Perluasan karsinoma nasofaring ke dalam rongga hidung, fossa infratemporal, orbita dan rongga kranial sangat baik diperlihatkkan oleh pemeriksaan CT dengan penyangatan kontras (Ballenger, 2003). Kontras enhancement yang dihasilkan oleh media kontras setelah masuk pembuluh darah dibutuhkan untuk mengetahui jika terjadi invasi pada basis cranii, membedakan kontras gambar antara jaringan normal dan abnormal serta untuk mengetahui karakteristik beberapa lesi (Seeram, 2001).
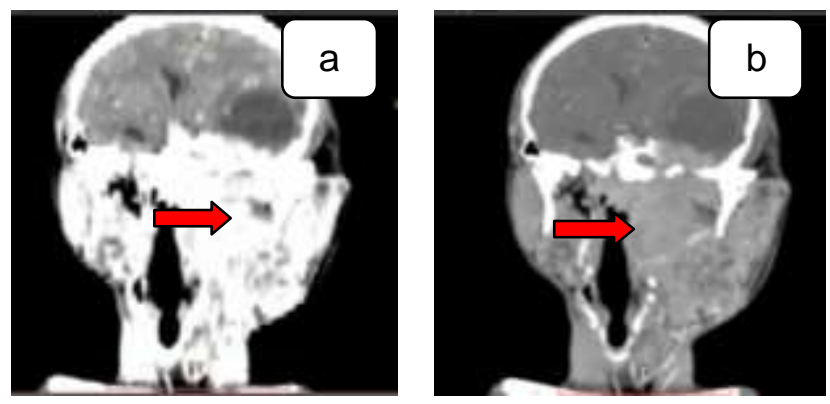

Gambar 5 Sampel hasil MSCT Nasofaring dengan klinis karsinoma pada citra potongan coronal (a) dengan pemilihan slice thickness 5 $\mathrm{mm}$ dan variasi rekonstruksi increment overlapping $1 \mathrm{~mm}$ dan (b) dengan pemilihan slice thickness $3 \mathrm{~mm}$ dan variasi reconstruksi increment overlapping $50 \%$ (1,5 mm). Keterangan : tanda panah menunjukkan perluasan massa dari karsinoma nasofaring

Interprestasi hasil uji hipotesa juga menunjukkan bahwa tiap-tiap organ penilaian citra potongan axial mendapatkan skor keterpengaruhan yang kuat yaitu $59 \%$ pada organ nasofaring space, $58 \%$ pada organ resessus phryngeus lateralis (fossa Rossenmuller), 55\% pada organ torus tubarius, $50 \%$ pada organ parapharingeal space, $48 \%$ pada organ sinus paranasal, $51 \%$ pada organ internal carotid artery dan $45 \%$ pada organ kelenjar getah bening (KGB) leher. Sedangkan citra potongan coronal juga mendapatkan skor keterpengaruhan yang kuat yaitu 58\% pada organ nasofaring space, $55 \%$ pada organ resessus phryngeus lateralis (fossa Rossenmuller), 54\% pada organ torus tubarius, 52\% pada organ parapharingeal space, $48 \%$ pada organ sinus paranasal, 53\% pada organ internal carotid artery dan $36 \%$ pada organ kelenjar getah bening (KGB) leher. Hasil tersebut menggambarkan bahwa kenaikan rekonstruksi increment overlapping mempunyai pengaruh meningkatkan informasi citra anatomi pada setiap organ penilaian pada pemeriksaan MSCT Nasofaring dengan klinis karsinoma sehingga bisa membantu dalam penegakan diagnosa yaitu penentuan stadium, evaluasi keterlibatan tulang dan desruksi akibat tumor, melihat luasnya invasi tumor, menentukan besarnya tumor, mendeteksi adanya metastasis regional, serta memantau respon tumor terhadap terapi radiasi dan kemoterapi (Hartanto et al. 2011).

\section{SIMPULAN}

Ada pengaruh variasi rekonstruksi increment overlapping terhadap informasi citra anatomi pada pemeriksaan MSCT Nasofaring dengan klinis karsinoma dengan $p$ value $=0,000$ ( $p$ value $<0,05)$. Nilai rekonstruksi 
increment overlapping terbaik yang dapat memberikan informasi citra anatomi optimal pada pemeriksaan MSCT Nasofaring dengan klinis karsinoma yaitu rekonstrusi increment overlapping $50 \%(1,5 \mathrm{~mm})$ dari slice thickness 3 $\mathrm{mm}$.

Direkomendasikan penggunaan rekonstruksi increment overlapping $50 \%$ (1,5 mm) dari slice thickness $3 \mathrm{~mm}$ sebagai parameter untuk pemeriksaan MSCT Nasofaring dengan klinis karsinoma.

\section{DAFTAR PUSTAKA}

Adams, Goerge L., Boies, Lawrence R. 1997. BOIES Buku Ajar Penyakit THT. Edisi 6. EGC : Jakarta.

Baiq. 2012. Teknik Pemeriksaan MSCT pada Pasien dengan Kasus Karsinoma Nasofaring di Sub Departemen Radiologi RSAL Dr. Ramelan Surabaya. Jurusan Teknik Radiodiagnostik dan Radioterapi, Poltekkes Kemenkes Semarang.

Ballenger J.J. 2001. Penyakit Telinga, Hidung, Tenggorok, Kepala dan Leher. Jilid 1. Binarupa Aksara Publisher : Tanggerang.

Brink et.al 1994. Helical CT : Principles and Technical Considerations. http://radiographics.rsna.org/content/14/4/887.full.pdf Diakses tanggal 12 September pukul 20.00 WIB

Boas, F.E. and Fleischmann D. 2012. CT Artifact : Cause and Reduction Technique. Departement of Radiology, Stanford University : USA.

Bontranger, K.L. 2010. Textbook of Radiographic Positioning and Related Anatomy. Seventh Edition. Mosby Elsevier : St. Louis Missouri.

Busberg J.T. 2002. The Essential Physics of Medical Imaging. Second Edition. Lippincott Williams and Walkins : Philadelphia.

Herawati, S., Rukmini, S. 2000. Buku Ajar Ilmu Penyakit THT untuk Mahasiswa Fakultas Kedokteran Gigi. EGC : Jakarta.

Hartanto,H., Suyono, J., Matahari, Diani, A., Kosasih, A.A., Mahanani, D.A. 2011. Ilmu THT Esensial. Edisi 5. EGC : Jakarta.

Hoffer, M. 2005. CT Teaching Manual : A Systematic Approach to CT Reading. Second Edition. Thieme Book Company : USA.

Morton, D.A., Foreman,K.Bo. Albertine, K.H. 2011. The Big Picture : Gross Anatomy. Mc Graw Hill Medical : New York.

Netter, F.H. 2014. Atlas of Human Anatomy. 6th Edition. Saunders : USA.

Ryan, S., McNicholas, M., Eustace,S. 2011. Anatomy for Diagnostic Imaging. Third Edition. Saunders : New York.

Romans, L.E. 2011. Computed Tomography for Technolgist A Comprehensive Text. Wolters Kluwer Health, Lippincott Williams \& Wilkins : Philadelphia.

Saini, S. 2006. MDCT A Practical Approach. Springer : Italia.

Seeram, E. 2001. Computed Tomography : Physical Principles, Clinical Application and Quality Control, Second Edition. WB Saunders Company : Philadelphia.

Siemens Medical. 2003. Computed Tomography : Its History and Technology. Siemens Medical Solution. Germany. www.SiemensMedical..com. Diakses tanggal 12 September 2016 pukul 20.00 WIB

Soepardi, E.A., Iskandar, N. 2007. Buku Ajar THT. Edisi keenam. Gaya Baru : Jakarta.

Syaifuddin. 2016. Anatomi Fisiologi : kurikulum berbasis kompetensi untuk keperawatan \& kebidanan. EGC : Jakarta.

Sopiyudin, M. 2014. Statistik untuk Kedokteran dan Kesehatan. Buku Seri 1 Edisi 6. Epidemiologi Indonesia : Jakarta. 